\title{
Fungal isolates from marine sponge Chelonaplysilla sp.: Diversity, antimicrobial and cytotoxic activities
}

\author{
DIAN HANDAYANI ${ }^{1, \bullet}$, MUH. ADE ARTASASTA ${ }^{1,2}$, NILDA SAFIRNA ${ }^{1}$, DIANA FITRI AYUNI ${ }^{1}$, \\ TRINA EKAWATI TALLEI ${ }^{3}$, TRIANA HERTIANI ${ }^{4}$ \\ ${ }^{1}$ Sumatran Biota Laboratory, Faculty of Pharmacy, Universitas Andalas. Jl. Unand, Kampus Limau Manis, Padang 25163, West Sumatra, Indonesia. \\ ${ }^{2}$ Department of Biomedical, Faculty of Medicine, Universitas Andalas. Jl. Unand, Kampus Limau Manis, Padang 25163, West Sumatra, Indonesia. Tel.: \\ +62-751-31746. `email: dianhandayani@phar.unand.ac.id \\ ${ }^{3}$ Department of Biology, Faculty of Mathematics and Natural Sciences, Universitas Sam Ratulangi. Kampus UNSRAT Kleak, Manado, 95115, North \\ Sulawesi, Indonesia \\ ${ }^{4}$ Faculty of Pharmacy, Universitas Gadjah Mada. J1. Kaliurang, Sekip Utara, Sleman 55281, Yogyakarta, Indonesia
}

Manuscript received: 3 February 2020. Revision accepted: 13 April 2020.

\begin{abstract}
Handayani D, Artasasta MA, Safira N, Ayuni DF, Tallei TE, Hertiani T. 2020. Fungal isolates from marine sponge Chelonaplysilla sp.: Diversity, antimicrobial and cytotoxic activities. Biodiversitas 21: 1954-1960. The purpose of this research was to study the diversity of fungi associated with marine sponges Chelonaplysilla sp. and their bioactivities. Fungal isolation was carried out by the multilevel dilution method in Saboraud Dextrose Agar (SDA). Twelve fungal isolates were successfully purified, then cultivated using rice for 4-6 weeks at room temperature and subsequently extracted using ethyl acetate. Antimicrobial activities of the fungal extracts were tested against Staphylococcus aureus, Escherichia coli, and Candida albicans by using the agar diffusion method. The extracts of isolates $\mathrm{Ch} 05$ and $\mathrm{Ch} 12$ showed a significant antagonistic effect against $S$. aureus and $E$. coli with the diameter that ranged from 15 to $17 \mathrm{~mm}$. Using the brine shrimp lethality test (BSLT), six fungal extracts revealed cytotoxic activity with LC $50<100 \mu \mathrm{g} / \mathrm{mL}$. Isolate Ch10 was the most potential fungus with the strong cytotoxic activity of LC50 of $0.90 \mu \mathrm{g} / \mathrm{mL}$. The 3-(4,5-dimethylthiazol-2-yl)2,5-diphenyltetrazolium bromide (MTT) assay was conducted also for six potential fungal extracts against breast cancer cell (T47D). The isolate Ch05 showed moderate cytotoxic activity with $\mathrm{IC}_{50}$ of $83.69 \mu \mathrm{g} / \mathrm{mL}$. The molecular identification was carried out for potential fungi using the ITS marker. The results showed that Ch02 was Aspergillus oryzae, Ch05 was Phomompsis sp., Ch06 was Penicillium simplicissimum, Ch10 was B. bassiana and Ch12 was Aspergillus mellinus. This study concluded that fungal isolates from marine sponge Chelonaplysilla sp. can be explored further for new sources of antimicrobial and anticancer compounds.
\end{abstract}

Keywords: Antimicrobial, Chelonaplysilla, cytotoxic, marine-derived fungi

\section{INTRODUCTION}

Bioactive compounds produced by fungi associated with marine sponges have shown potential pharmacological activities and have similar metabolites produced by their hosts (Indraningrat et al. 2016; Youssef et al. 2019). These types of fungi are thought to be the original producer of bioactive compounds in sponges (Proksch et al. 2002). Several new bioactive compounds from marine associated fungi have shown potential new bioactivities, for example, secondary metabolites produced by Aspergillus similanensis contained similanpyrone $\mathrm{C}$, similanamide, and pyripyropene (Thomas et al. 2010; Prompanya et al. 2015). Averantin isolated from A. versicolor associated with marine sponge Neopetrosia sp. was proven to have antibacterial and cytotoxic activities (Lee et al. 2010).

Marine sponges which were collected from Mandeh island in west Sumatra-Indonesia were known to be associated with potential fungi which produced antimicrobial and cytotoxic activities (Artasasta et al. 2017; Handayani and Aminah 2017; Handayani and Artasasta 2017; Aminah et al. 2019; Handayani et al. 2019a, 2019b). This study focused to discover the diversity of Chelonaplysilla sp. associated fungi and their biological activities against pathogens and breast cancer cells (T47D).

\section{MATERIALS AND METHODS}

The extraction process of the pure fungal isolate from marine sponge Chelonaplysilla sp.

Marine sponge Chelonaplysilla sp. (Fig. 1) from Mandeh island, west Sumatra-Indonesia (1o 6'-1o 13'S, 100o 19'-100o 25'E) (Fig. 2) was used as a fungal source. Identification of the sponge was conducted by Dr. Nicole J. De Voogd, at the Natural Biodiversity Center, Netherland. The fungal isolation was conducted following our previous study using a multi dilution method (Handayani and Artasasta 2017). Pure isolates were cultivated on rice media at room temperature for 4-6 weeks. The extraction process was conducted after the fungal isolates overgrew on the media. Ethyl acetate was used for extracting nonpolar and semi-polar compounds of the fungal isolates with the ratio of $200 \mathrm{~mL}$ solvent to $100 \mathrm{mg}$ rice. To complete the extraction process, the fungi were immersed in the ethyl acetate for 3 days. The solvent was evaporated to obtain the dry extracts that were used for antimicrobial and cytotoxic activity as well as phytochemical tests. 


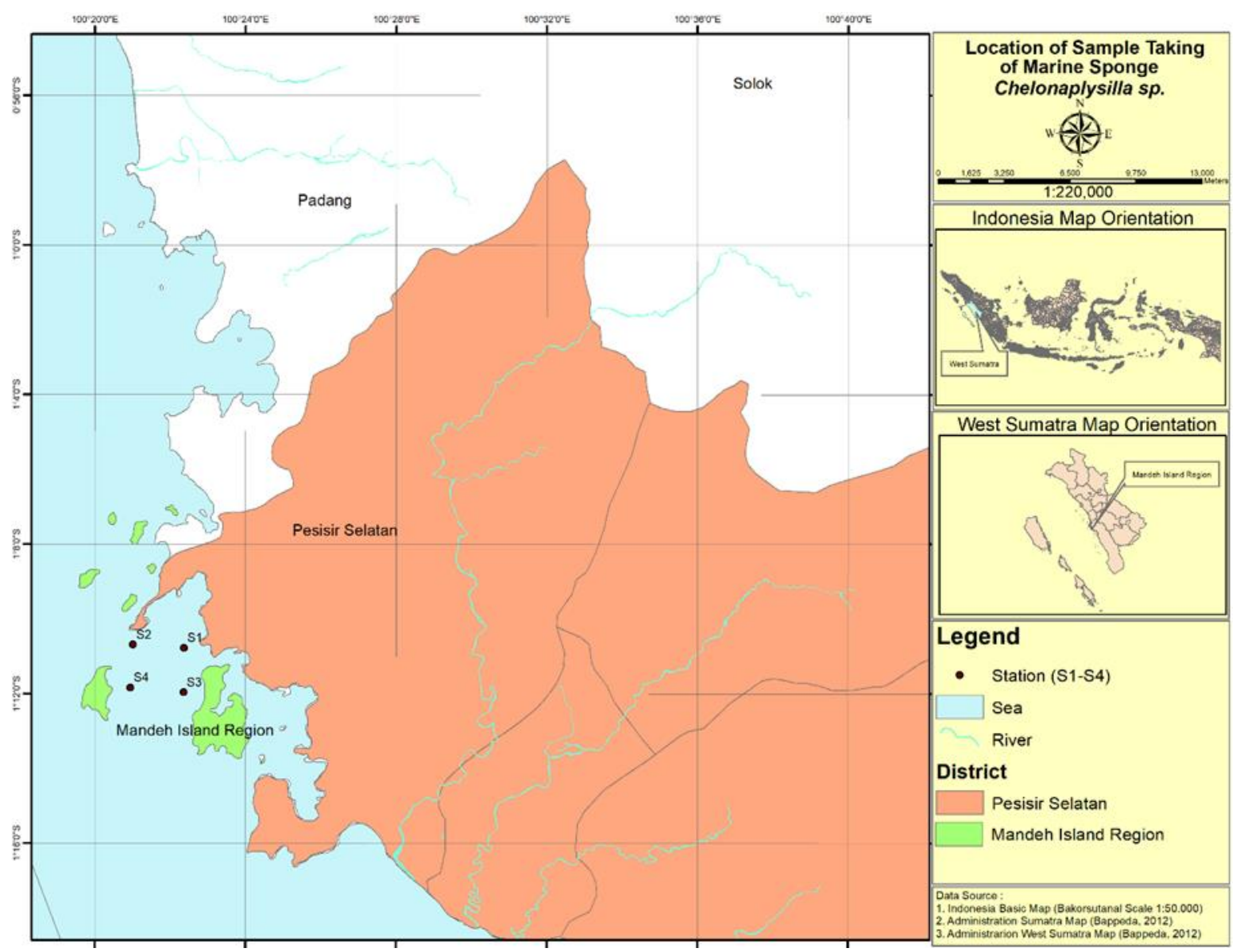

Figure 2. Location of sample taking of marine sponge Chelonaplysilla sp. in Mandeh Island, West Sumatra, Indonesia ( $1^{\circ} 6^{\prime}-1^{\circ} 13^{\prime} \mathrm{S}$, $\left.100^{\circ} 19^{\prime}-100^{\circ} 25^{\prime} \mathrm{E}\right)$

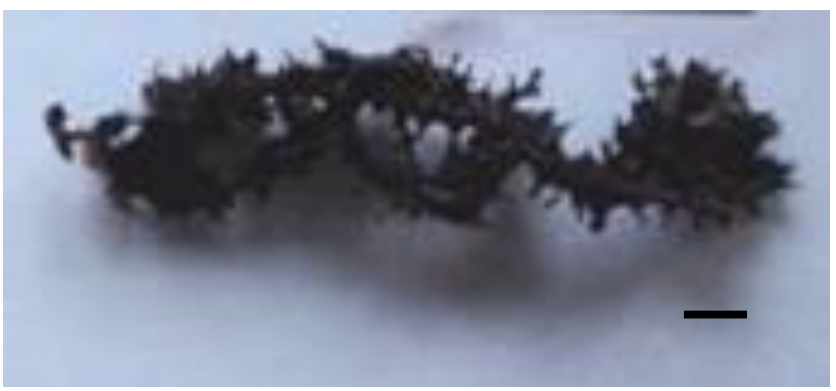

Figure 1. Marine sponge Chelonaplysilla sp. $\mathrm{Bar}=1 \mathrm{~cm}$

\section{Screening of antimicrobial activity}

S. aureus ATCC 2592, E. coli ATCC 25922, and C. albicans were used as the pathogens for antimicrobial screening. This study followed the procedure provided by Balouiri et al (2016) using the agar diffusion method. Sterile paper disk $(6 \mathrm{~mm})$ was soaked in each of $5 \%$ fungal extract. Nutrient agar (NA) was used for an antibacterial test, while SDA was used as media for an antifungal test. As positive controls, $30 \mu \mathrm{g} / \mathrm{disc}$ chloramphenicol (antibacterial) and nystatin (antifungal) were used. After incubation for $24 \mathrm{~h}$ at room temperature, the diameter of inhibition zones $(\mathrm{mm})$ was measured as an indication of antagonistic effects.

\section{Screening of cytotoxic activity BSLT}

BSLT was used for the evaluation of cytotoxic activity. The eggs of Artemia salina were hatched in seawater for 2 days at $37^{\circ} \mathrm{C}$. After hatching, 10 active nauplii were put into a test tube containing the fungal extracts which were dissolved in DMSO (dimethyl sulfoxide) up to a concentration of 1000, 100 and $10 \mu \mathrm{g} / \mathrm{mL}$. Probit analysis was used for determining the value of LC50 (Meyer et al. 1982).

\section{Cytotoxicity assay}

MTT assay was carried out to study the cytotoxic activity of fungal extracts against breast cancer cell T47D. These cells were seeded at $1 \times 10^{5}$ cells $/ \mathrm{mL}$ in 96 well microtiter plates containing DMEM (Dulbecco's modified Eagle's medium), a modification of Basal Medium Eagle 
(BME). The cells could attach on the well overnight. Once the cells were confluent, $20 \mu \mathrm{L}$ of the fungal extract was added to the well with various concentrations $(1000,500$, $250,125,62.5$, and $31.25 \mu \mathrm{g} / \mathrm{mL}$ ) then the plates were placed in $5 \% \mathrm{CO} 2$ incubator at $37 \mathrm{oC}$ for $24 \mathrm{~h}$. Thereafter, the media were replaced with PBS. The cells were subsequently treated with $5 \mathrm{mg} / \mathrm{mL} 3$-[4,5-dimethylthiazol2-yl]-2,5-diphenyltratrazolium bromide (MTT) (Sigma Chemical Co., St. Louis, MO) and incubated for 4 hours. DMSO was used to dissolve the remaining formazan crystals. Using ELISA reader, the absorbance was measured at $570 \mathrm{~nm}$. The percentage of viability of the cells was determined then converted into the IC50 value (Artasasta et al. 2017).

\section{Fungal identification}

\section{Macroscopic and microscopic identification}

Macroscopic appearance of the fungi such as color, the diameter of the colony, and colony reverse was observed. Microscopic observation was conducted by using a lactophenol cotton blue solution as a mounting medium and staining agent. The hyphae were put on a slide then mixed with fungal coloring. Conidiophores, vesicles, and conidia were observed under a light microscope (Charya and Garg 2019).

\section{Molecular identification}

Molecular identification was performed using ITS1 primer (F5'-TCC GTA GGT GAA CCT GCG G-3') and ITS4 primer (R5'-TCC TCC GCT TAT TGA TAT GC-3') with the two-step procedure, DNA extraction, and PCR amplification. DNA extraction was conducted by following Saitoh et al., (2016). The PCR process was conducted by 34 cycles included denaturation at $950 \mathrm{C}$ for $5 \mathrm{~min}$, annealing at $55 \mathrm{oC}$ for $1 \mathrm{~min}$, and extension at $72^{\circ} \mathrm{C}$ for 1 min (Ferrer et al. 2001). The PCR products were sequenced in First Base Malaysia then were trimmed and assembled by using BioEdit V.7.0.5. Furthermore, the sequences were subjected to identification using the BLAST program on NCBI. The Neighbor-Joining (NJ) phylogenetic tree was generated by MEGA 7.0 software (Kumar et al. 2016), using Kimura-2-Parameter with 1,000 bootstrap replications.

\section{Secondary metabolites examination}

The standard protocol of Harborne (1984) was followed in this step. Dragendorff reagent for alkaloid, Lieberman Bourchard's reagent for terpenoid and steroid, $\mathrm{FeCl}_{3}$ reagent for phenolic, and Citroborat reagent for flavonoid were used. The fungal extract was spotted on the G60 F254 silica plate then eluted with $n$-hexane: ethyl acetate eluent (1: 4). Each of the reagents was swapped to each different silica. Each of the secondary metabolites produced different colors based on different reagents. The orange color indicated the presence of alkaloid, pink color for terpenoid, blue or green color for the steroid, purple, red, or pink colors for phenolic, and green color for flavonoid (Harborne 1984).

\section{RESULTS AND DISCUSSION}

\section{Antimicrobial activity of marine sponge derived fungi}

Twelve fungal isolates were purified from marine sponge Chelonaplysilla sp. This sponge was known to exhibit antimicrobial and cytotoxic compounds (Bobzin and Faulkner 1991a, 1991b). Presumably, the bioactive compounds were produced by its associated fungi. Although the active compound produced by the fungus associated with Chelonaplysilla sp. has never been reported before, some studies stated the family of this genus was associated with the fungus Streptomyces sp. which has broad-spectrum antimicrobial activity (Selvin et al. 2004; Selvin 2009; Selvin et al. 2009). Antimicrobial activity from twelve fungal extracts showed different results (Table 1). Among all isolates, only three isolates ( $\mathrm{Ch05,} \mathrm{Ch06}$, and Ch12) performed strong antagonistic activity against both $S$. aureus and $E$. coli. These fungal extracts could be categorized as broad-spectrum because of their abilities to inhibit the growth of both Gram-negative and Grampositive pathogenic bacteria. Isolate $\mathrm{Ch} 12$ was the most potential isolate with a diameter inhibition zone of $16.69 \pm$ 0.51 and $7.96 \pm 0.73 \mathrm{~mm}$, respectively. However, there was no fungal extract that showed a strong antagonistic effect against $C$. albicans.

Table 1. Antimicrobial activity result of fungal extracts from marine sponge Chelonaplysilla sp.

\begin{tabular}{|c|c|c|c|}
\hline \multirow{2}{*}{$\begin{array}{c}\text { Fungal } \\
\text { isolates code }\end{array}$} & \multicolumn{3}{|c|}{$\begin{array}{c}\text { Diameter inhibition zone }(\mathrm{mm}) \pm \text { Standard } \\
\text { Deviation }(\text { SD) }\end{array}$} \\
\hline & S. aureus & E. coli & C. albicans \\
\hline Ch01 & - & $7.83 \pm 0.79$ & - \\
\hline $\mathrm{Ch} 02$ & $8.83 \pm 1.01$ & $8.54 \pm 1.00$ & - \\
\hline $\mathrm{Ch} 03$ & $8.25 \pm 0.35$ & - & - \\
\hline $\mathrm{Ch} 04$ & $8.13 \pm 0.76$ & $9.34 \pm 2.03$ & $8.13 \pm 0.99$ \\
\hline Ch05 & $15.92 \pm 0.52$ & $16.33 \pm 0.51$ & $7.54 \pm 0.19$ \\
\hline Ch06 & $11.96 \pm 0.79$ & $12.29 \pm 0.72$ & $7.88 \pm 0.71$ \\
\hline $\mathrm{Ch} 07$ & - & $7.71 \pm 0.69$ & - \\
\hline $\mathrm{Ch} 08$ & $8.75 \pm 0.87$ & $9.54 \pm 1.44$ & - \\
\hline Ch09 & - & - & $8.67 \pm 0.36$ \\
\hline Ch10 & - & $7.88 \pm 076$ & $7.63 \pm 1.19$ \\
\hline Ch11 & - & $8.17 \pm 1.02$ & $8.56 \pm 0.09$ \\
\hline Ch12 & $16.69 \pm 0.51$ & $16.88 \pm 0.57$ & $7.96 \pm 0.73$ \\
\hline
\end{tabular}

Note: The value is expressed as the mean \pm standard deviation; $\mathrm{n}=3$

Table 2. MTT assay of the extracts of fungi isolated from marine sponge Chelanoplysilla sp. against breast cancer cell T47D

\begin{tabular}{ll}
\hline Fungal isolates code & IC $_{\mathbf{5 0}}(\boldsymbol{\mu g} \mathbf{g} \mathbf{m L})$ \\
\hline Ch 01 & 605.72 \\
Ch 02 & 743.42 \\
Ch 05 & 83.96 \\
Ch 09 & 641.19 \\
Ch 10 & 670.75 \\
Ch 12 & 637.24 \\
\hline
\end{tabular}




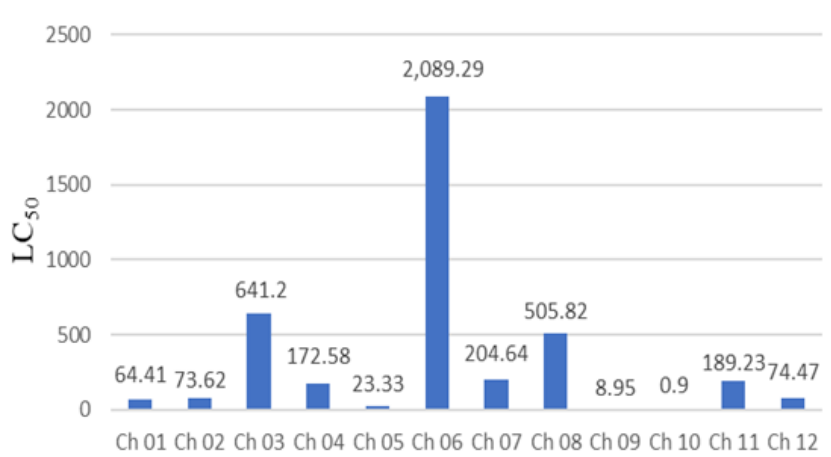

Fungal isolates code

Figure 3. Cytotoxic activity results of the extracts of fungi isolated from marine sponge Chelanoplysilla sp. by using BSLT method

\section{Cytotoxic activity of marine sponge derived fungi}

BSLT is one of the preliminary toxicity tests for the active compound obtained from the fungal extract. This method is comparable to expensive bioassay methods (Pisutthanan et al., 2004; Wu, 2014). In this study, six fungal isolates (Ch01, Ch02, Ch05, Ch09, Ch10, and Ch12) had $\mathrm{LC}_{50}$ value $<100 \mu \mathrm{g} / \mathrm{mL}$ (Fig. 3). These isolates could be categorized as having strong cytotoxic activities according to Meyer et al., (1982). Among these isolates, isolate $\mathrm{Ch} 10$ had the lowest $\mathrm{LC}_{50}$ value $(0.90 \mu \mathrm{g} / \mathrm{mL})$. MTT assay was also conducted for these six potential fungi against breast cancer cell T47D (Table 2). The isolate Ch05 fungal exhibited moderate cytotoxic activity with $\mathrm{IC}_{50}$ 83.69 $\mu \mathrm{g} / \mathrm{mL}$. Other isolates did not provide enough cytotoxic activity on these cell lines. Presumably, every cancer cell has its sensitivity against each anticancer agent.

\section{Macroscopic, microscopic, and molecular identification of marine sponge derived fungi}

Antimicrobial and cytotoxic assays revealed that isolates $\mathrm{Ch} 02, \mathrm{Ch} 05, \mathrm{Ch} 06, \mathrm{Ch} 10$, and $\mathrm{Ch} 12$ strains were the most potential to be studied further. Fungal identification of these isolates was conducted macroscopically, microscopically (Fig. 4), and molecularly (Fig. 5 and Tab. 3). From the phylogenetic tree, it was seen the grouping of each isolate following the results of identification.

The surface observation of isolate $\mathrm{Ch02}$ exhibited a white cotton colony and showed a white color in the reverse colony. The diameter of the colony after 5 days was $7 \mathrm{~cm}$ (A1). Conidiophore and asexual spore of this isolate were similar to those of genus Aspergillus. The surface of the colony of isolate Ch05 was observed to have white threads appearance. The colony diameter after 5 days was $10 \mathrm{~cm}$ (B1). This isolate had light blue conidiophore, and asexual spores of this fungus were similar to genus Phomompsis (B2). Isolate Ch06 had a dark green surface colony. Its reverse colony was gray color with diameter after 5 day-growth was 5-6 cm (C1). This isolate had gray conidiophore and asexual spores which were similar to genus Penicillium. Isolate Ch12 had a white colony with a rough surface after 5 days, the diameter of the colony was around 3-5 cm (E1). This fungus had blue light conidiophore and striated vesicle. These characters place this fungus similar to genus Aspergillus (E2). Isolate Ch10 had a white surface colony with a diameter of $8-10 \mathrm{~cm}$ after 10 days. This fungus had gray conidiophore (D1). Asexual spores of this fungal were similar to genus Beauveria (D2).

The results of molecular identification for isolate Ch02, Ch05, Ch06, Ch10, and Ch12 are presented in Table 3 and Figure 4. The conclusions drawn based on the results of identification using the ITS gene indicated that $\mathrm{Ch02}$ had a $100 \%$ identity with Aspergillus oryzae and Aspergillus. flavus. The $100 \%$ identity between these to fungal species resulted in uncertainty regarding the identification method. According to Frisvad et al (2019), A. oryzae was the result of domestication of A. flavus, thus giving confusion to the naming of those unfamiliar with the morphological characteristics of these two fungi. To distinguish the two, a suggestion will be placed such as the examination of aflatoxins, since $A$. oryzae lost its ability to produce aflatoxin, although phylogenetically it is very closely related to A. flavus. Aspergillus oryzae produced 4hydroxy-4-methylpent-2-enyl moiety which was assumed to inhibit the growth of $E$. coli while A. flavus produced a compound that showed a strong inhibition activity against S. aureus (Xu et al. 2015).

Three portals used to identify fungi molecularly gave different results based on the ITS gene sequence of isolate Ch05. The GenBank identified this isolate as Phomapsis sp. (99.8\%), Mycobank revealed identity $97.51 \%$ with $P$. perseae, while BOLD identified this isolate as Diaporthe hongkongensis (99.2\%). Phomopsis actually is the asexual stage of Diaporthe (Gomes et al. 2013). Kobayashi et al (2003), was able to isolate phomopsidin produced by Phomopsis sp., a marine-derived fungus. Using GenBank and BOLD, Ch06 was confirmed molecularly as Penicillium simplicissimum. $\mathrm{Zu}$ et al (2016), reported the presence of three new dihydroisocoumarins produced by $P$. simplicissimum MA-332, a fungus derived from marine mangrove, which showed toxicity activity against brine shrimp and broad-spectrum antimicrobial activities.

Isolate Ch10 was identified by GenBank as Beauveria bassiana, and this result was in line with the results obtained from MycoBank and BOLD. Yamazaki et al (2012) reported that they were able to isolate chrysazin and globosuxanthone A from B. bassiana TPU942, a marinederived fungus. Chrysazin and globosuxanthone A were able to inhibit the growth of $C$. albicans, and globosuxanthone A showed cytotoxic activity against two human cancer cell lines, HCT-15 (colon) and Jurkat (T-cell lymphoma). Isolate $\mathrm{Ch} 12$ was verified molecularly as Aspergillus mellinus. Aspergillus mellinus RSPG_204 showed antimicrobial activities against $S$. aureus, $P$. aeruginosa and $C$. albicans, and high cytotoxic activity against MCF7 (breast) cell line (El-Hady et al. 2014). The results from secondary metabolites analysis showed that Ch12 contained terpenoid, while Ch 10 contained saponin.

Terpenoid compounds have been widely isolated from Aspergillus genus. Most of the terpenoid compounds also have antimicrobial and cytotoxic activities. Aspergilloxide, a terpenoid compound from the marine-derived fungus 
Aspergillus sp. has potent cytotoxic activity toward HCT 116 colon carcinoma (Cueto et al. 2002). Another terpenoid compound from Aspergillus sp., asterpenols A and B, was known also as a potent antimicrobial (Xiao et al. 2013). Less information provided on saponin compounds from $B$. bassiana. Nevertheless, B. bassiana has been explored by several researchers. Beauvericin, a major compound from B. bassiana, is a potent cytotoxic. This compound also has another bioactivity such as antimicrobial, antiviral and insecticidal (Wang and $\mathrm{Xu}$ 2012). Pyridovericin and pyridomacrolidin, other compounds from B. bassiana, have been reported to have antimicrobial and cytotoxic activities (Takahashi et al. 1998).
In summary, fungal isolate $\mathrm{Ch} 12$ and $\mathrm{Ch} 10$, from marine sponge Chelanoplysilla sp., showed potential antimicrobial and cytotoxic activities, respectively. Molecular identification revealed that $\mathrm{Ch} 12$ was $A$. mellinus and $\mathrm{Ch} 10$ was $B$. bassiana. Isolate $\mathrm{Ch} 10$ and $\mathrm{Ch}$ 12 have already submitted to NCBI with accession number of MT000965 and MT003976, respectively. Further study is important to conduct due to the presence of secondary metabolites which can be investigated further for the possibility of being developed as antimicrobial and anticancer agents.

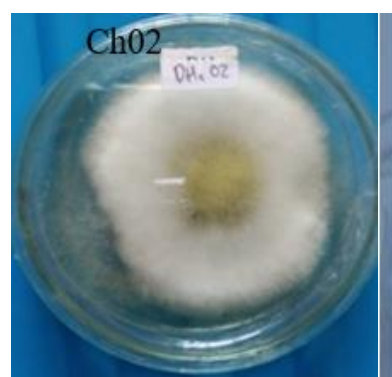

A1

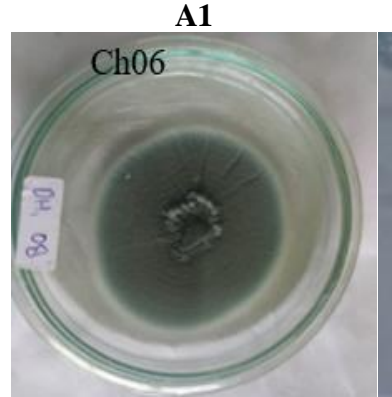

C1

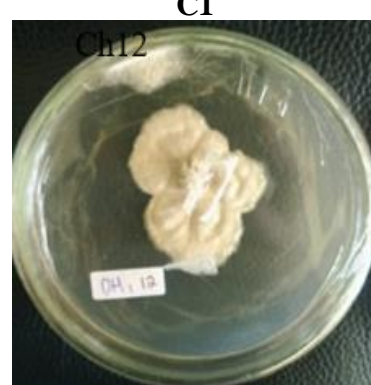

E1

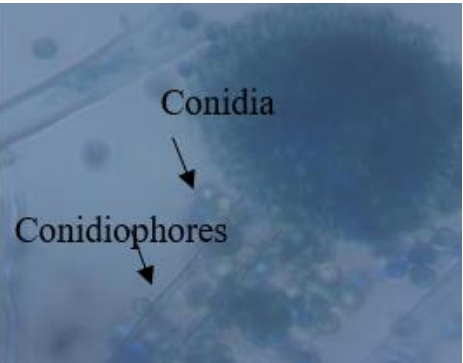

A2

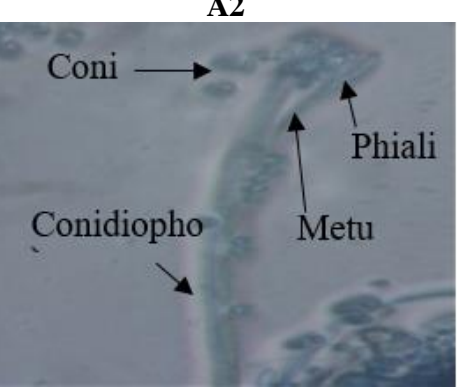

C2

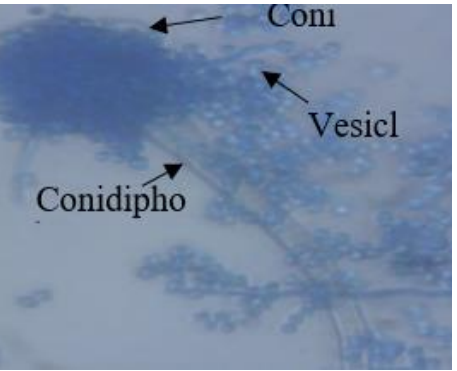

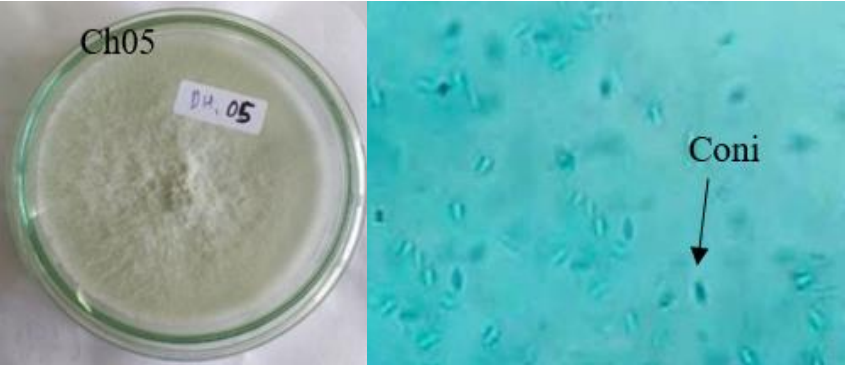

B1

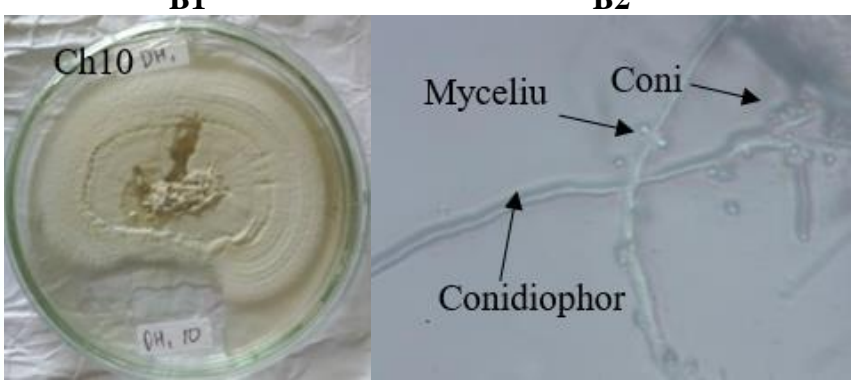

D1
D2

Figure 4. Macroscopic and microscopic identification of fungal isolates Ch02, Ch05, Ch06, Ch10, and Ch12

Table 3. The results of Molecular identification of fungal isolates Ch02, Ch05, Ch06, Ch10, and Ch12

\begin{tabular}{clllll}
\hline $\begin{array}{c}\text { Fungal } \\
\text { isolates code }\end{array}$ & \multicolumn{1}{c}{ GenBank } & Identity (\%) & MycoBank & Identity (\%) & BOLD \\
\hline Ch02 & Aspergillus oryzae & $100 \%$ & A. flavus & $100 \%$ & A. oryzae, A. flavus \\
Ch05 & Phomapsis sp. & 99.80 & P. perseae & 97.51 & Diaporthe hongkongensis \\
Ch06 & P. simplicissimum & 100 & P. rolfsii & 97.461 & P.simplicissimum \\
Ch10 & Beauveria bassiana & 100 & B. bassiana & 99.184 & B. bassiana \\
Ch12 & A. mellinus & 100 & A. mellinus & 100 & Aspergillus mellinus \\
\hline
\end{tabular}




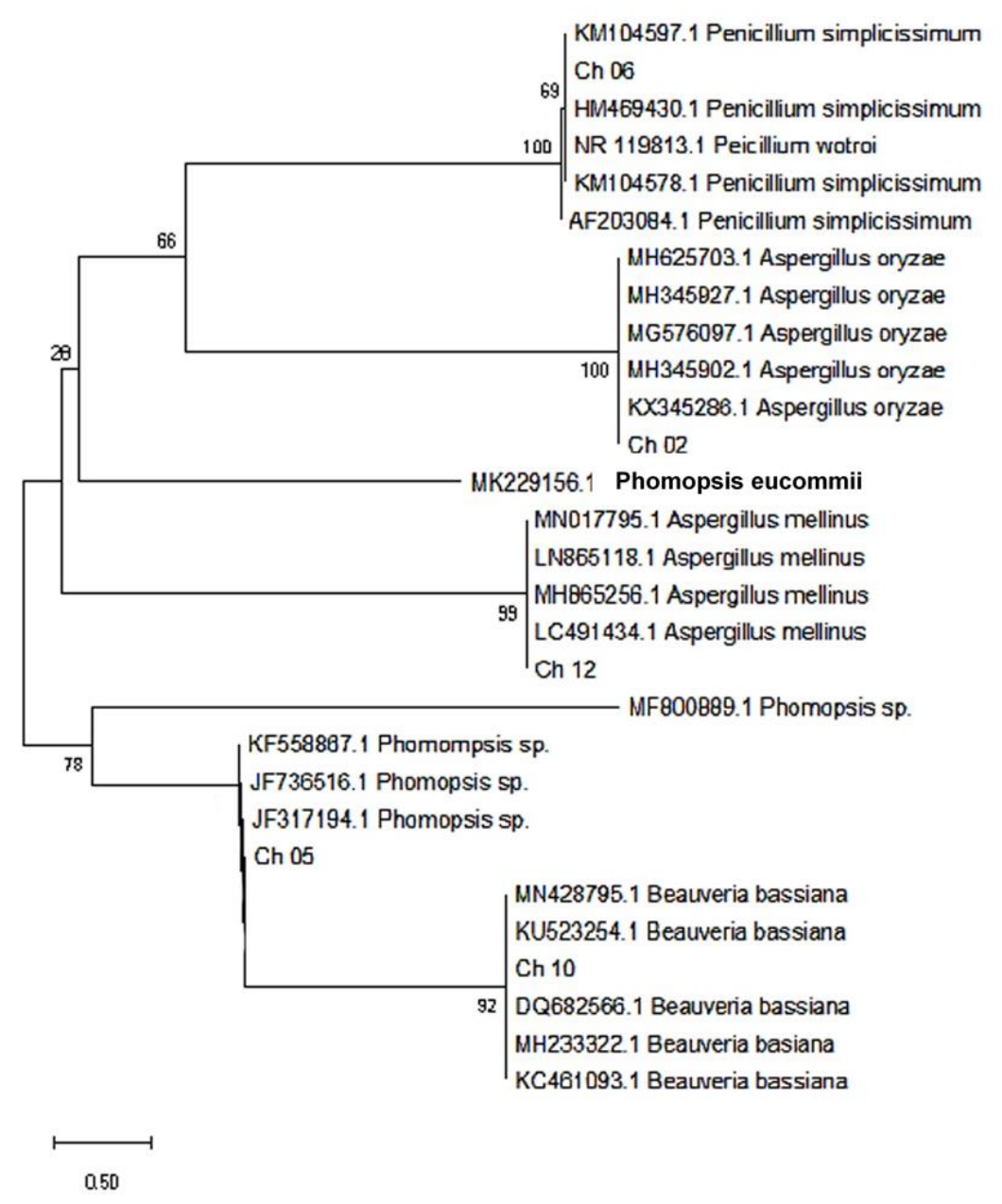

Figure 5. The phylogenetic tree of ITS sequences of fungal isolate Ch02, Ch05, Ch06, Ch10, and Ch12 inferred using the NeighborJoining method

\section{ACKNOWLEDGEMENTS}

This research was supported by BOPTN of Andalas University, Padang, Indonesia, in the project of "Penenelitian Dasar Unggulan Klaster Riset-Publikasi Guru Besar Universitas Andalas (PDU-KRP1GB-Unand)", No. T/32/UN.1617/PP.OK-KRP1GB/LPPM/2019 We are also grateful to Dr. Nicole J. De Voogd, Natural Biodiversity Center, the Netherlands for the identification of the marine sponge.

\section{REFERENCES}

Aminah I, Putra AE, Arbain D, Handayani D. 2019. Screening of cytotoxic activities toward WiDr and Vero cell lines of ethyl acetate extracts of fungi-derived from the marine sponge Acanthostrongylophora ingens. J Appl Pharm Sci 9: 1-5.

Artasasta MA, Djamaan A, Handayani D. 2017. Cytotoxic activity screening of ethyl acetate fungal extracts derived from the marine sponge Neopetrosia chaliniformis AR-01. J Appl Pharm Sci 7: 174178.

Bobzin SC, Faulkner DJ. 1991a. Aromatics alkaloids from the marine sponge Chelonaplysilla sp. J Org Chem 56: 4403-4407.
Bobzin SC, Faulkner DJ. 1991b. Diterpenoids from the Pohnpeian marine sponge Cheloaplysilla sp. J Nat Prod 54: 225-232.

Balouiri M, Sadiki M, Ibnsouda SK. Methods for in vitro evaluating antimicrobial activity: A review. J Pharm Anal 6: 71-79.

Charya LS, Garg S. 2019. Advances in methods and practices of ectomycorrhizal research. 2TH ed. Adv Biol Sci Res 2019; 303-325. DOI: 10.1016/B978-0-12-817497-5.00019-7.

Cueto M, Jensen PR, Fenical W. 2002. Aspergilloxide, a novel sesterterpene epoxide from a marine-derived fungus of the genus Aspergillus. Org Lett 227: 2001-2003.

Ferrer C, Colom F, Frasés S, Mulet E, Abad JL, Alió JL. 2001. Detection and identification of fungal pathogens by PCR and by ITS2 and $5.8 \mathrm{~S}$ ribosomal DNA typing in ocular infections. J Clin Microbiol 39: 2873-2879.

Frisvad JC, Hubka V, Ezekiel CN, Hong SB. Nováková A, Chen AJ, Houbraken J. 2019. Taxonomy of Aspergillus section Flavi and their production of aflatoxins, ochratoxins and other mycotoxins. Stud Mycol 93: 1-63.

Gomes RR, Glienke C, Videira SIR, Lombard L, Groenewald JZ, Crous PW. 2013. Diaporthe: a genus of endophytic, saprobic and plant pathogenic fungi. Persoonia, 31: 1-41.

Hamed AA, Abdel-Aziz MS, Abd El Hady FK. 2018. Antimicrobial and antioxidant activities of different extracts from Aspergillus unguis SPMD-EGY grown on different media. Bull Natl Res Centre 42: 29. DOI: $10.1186 / \mathrm{s} 42269-018-0027-0$

Handayani D, Aminah I. 2017. Antibacterial and cytotoxic activities of ethyl acetate extract of symbiotic fungi from West Sumatra marine sponge Acanthrongylophora ingens. J Appl Pharm Sci 7: 237-240. 
Handayani D, Ananda N, Artasasta MA, Ruslan R, Fadriyanti O, Talle TE. 2019a. Antimicrobial activity screening of endophytic fung extracts isolated from brown algae Padina sp. J Appl Pharm Sci 9: 913.

Handayani D, Artasasta MA. 2017. Antibacterial and cytotoxic activities screening of symbiotic fungi extracts isolated from marine sponge Neopetrosia chaliniformis AR-01. J Appl Pharm Sci 7: 66-69.

Handayani D, Sandrawati N, Akbar S, Syafni N, Prima D. 2019b. Tyrosinase inhibitory activity of ethyl acetate extracts from marine sponge-derived Fungi. Biosci Res 16: 2369-2373.

Harborne JB. 1984. Methods of Plant Analysis. Chapman and Hall, London.

Indraningrat AAG, Smidt H, Sipkema D. 2016. Bioprospecting spongeassociated microbes for antimicrobial compounds. Mar Drugs 14: 166.

Kobayashi H, Meguro S, Yoshimoto T and Namikoshi M. 2003. Absolute structure, biosynthesis, and anti-microtubule activity of phomopsidin, isolated from a marine-derived fungus Phomopsis sp. Tetrahedron 59: 455-459.

Kumar S, Stetcher G, Tamura K. 2016. MEGA7: Molecular evolutionary genetics analysis version 7.0 for bigger datasets. Mol Biol Evol 33: 111.

Lee YM, Li H, Hong J, Cho HY, Bae KS, Kim MA, Kim DK, Jung JH. Bioactive metabolites from the sponge-derived fungus Aspergillus versicolor. Arch Pharm Res 33: 231-235.

Meyer BN, Ferrigni NR, Putnam JE, Jacobsen LB, Nicholis DE, McLaughin JL. 1989. Brine shrimp: a convenient general bioassay for active plant constituents. Planta Med 45: 31-34.

Pisutthanan S, Plianbangchang P, Pisutthanan N. 2004. Brine shrimp lethality activity of Thai medicinal plants in the family Meliaceae. Naresuan Univ J 12: 13-18.

Proksch P, Edrada RA, Ebel R. 2002. Drugs from the Seas-Current Status and Microbiological Implications. Appl Microbiol Biotechnol 59: 125-134.

Prompanya C, Fernandes C, Cravo S, Pinto MMM, Dethoup T, Silva AMS, Kijjoa A. 2015. A new cyclic hexapeptide and a new isocoumarin derivative from the marine sponge-associated fungus Aspergillus similanensis KUFA 0013. Mar Drugs 7: 1432-1450.

Sibero MT, Igarashi Y, Radjasa OK, Sabdono A, Trianto A, Zilda DS, Wijaya YJ. 2019. Sponge-associated fungi from a mangrove habitat in Indonesia: species composition, antimicrobial activity, enzyme screening and bioactive profiling. Intl Aquat Res 11: 173-186.
Selvin J, Joseph S, Asha KRT, Manjsha WA, Sangeetha VS, Jayaseema DM, Antany MC, Vinitha AJD. 2004. Antibacterial potential of antagonistic Streptomyces sp. isolated from marine sponge Dendrilla nigra. FEMS Microbiol Ecol 50: 117-122.

Selvin J. 2009. Exploring the antagonistic producer Streptomyces MS1051: implications of polyketide synthase gene type II and a ubiquitous defense enzyme phospholipase A2 in the host sponge Dendrilla nigra. Curr Microbiol 58: 459-463.

Selvin J, Shanmughapriya S, Gandhimathi R, Kiran GS, Ravji TR, Natarajaseenivasan K, Hema TA. Optimization and production of novel antimicrobial agents from sponge-associated marine actinomycetes Nocardiopsis dassonvillei MAD08. Appl Microbiol Biotechnol 83: 435-445

Takahashi S, Uchida K, Kakinuma N, Hashimoto R, Yanagisawa T, Nakagawa A. 1989. The structure of pyridovericin and pyridomacrolidin, new metabolites from the entomopathogenic fungus, Beauveria bassiana. J Antibiot (Tokyo) 51: 1051-1054.

Thomas TRA, Kavlekar DP, Lokabharathi PA. 2010. Marine drugs from sponge-microbe association — A review. Mar Drugs 8: 1417-1468

Wang Q, Xu L. 2012. Beauvericin, a bioactive compound produced by fungi: A short review. Molecules 17: 2367-2377.

Wu C. 2014. An important player in brine shrimp lethality bioassay: The solvent. J Adv Pharm Technol Res 5: 57-58.

Xiao Z, Huang H, Shao C, Xia X, Ma L, Huang X. 2013. Asperterpenols $\mathrm{A}$ and $\mathrm{B}$, new sesterterpenoids isolated from a mangrove endophytic fungus Aspergillus sp. 085242. Org Lett 15: 2522-2525.

Xu L, Meng W, Cao C, Wang J, Shan W \& Wang Q. 2015. Antibacterial and Antifungal Compounds from Marine Fungi. Mar Drugs 13 (6): 3479-3513.

Yamazaki H, Rotinsulu H, Kaneko T, Murakami K, Fujiwara H, Ukai K, Namikoshi M. 2012. A New Dibenz[b,e]oxepine Derivative, 1Hydroxy-10-methoxy-dibenz[b,e]oxepin-6,11-dione, from a MarineDerived Fungus, Beauveria bassiana TPU942. Mar Drugs 10 (12): 2691-2697.

Youssef FS, Ashour ML, Singab ANB, Wink M. 2019. A comprehensive review of bioactive peptides from marine fungi and their biological significance. Mar Drugs 17: 1-24.

Xu R, Li X-M, Wang B-G. 2016. Penicisimpins A-C, three new dihydroisocoumarins from Penicillium simplicissimum MA-332, a marine fungus derived from the rhizosphere of the mangrove plant Bruguiera sexangula var. rhynchopetala. Phytochemistry Lett 17; 114-118. 